\title{
Bridging the Gap: Pracademics in Foreign Policy
}

Ann Marie Murphy, Seton Hall University

Andreas Fulda, University of Nottingham

I $\mathrm{n}$ his seminal work Bridging the Gap: Theory and Practice in Foreign Policy, Alexander George (1993) lamented the great divide between academia and the foreign policymaking community, arguing that greater interaction between scholars and policymakers would produce better policy. We share George's belief that scholars and practitioners each have much to offer the other. In fact, a wide spectrum of opportunities exists for scholars in the field of political science to engage in meaningful public service that can enhance every aspect of their careers, as well as contribute to international understanding.

At the more purely academic end of this spectrum, scholars may be commissioned to conduct basic research for government agencies, think tanks, or nongovernmental organizations (NGOs). Moving in the direction of more practical activities, scholars may be hired to conduct policy analyses to evaluate existing policy or assess the policy implications of an unfolding event. At the more practical end of the spectrum, scholars may participate in Track II diplomacy and unofficial policy dialogues. Finally, academics can become policy advocates by directly lobbying for the adoption of specific policies. Some scholars not only follow George's advice to bridge the gap but go so far as to cross it by joining the government. Prominent examples of this shift include Condoleezza Rice, who left Stanford University to become secretary of state, and Joseph Nye, wholeft Harvard to become assistant secretary of defense. Both Rice and Nye returned to academia following their stint in government, illustrating the revolving door between the scholarly and policy worlds that exists for some pracademics.

In this article, we encourage scholars to think about how they can bridge this gap between political science in the academy and the sphere of foreign policymaking. We introduce readers to some of the opportunities available to them in this arena, offer advice on how to participate in these opportunities, and outline both the benefits of such practical work for teaching and research and the potential risks to an academic career. We are two political scientists whose backgrounds combine strong disciplinary training with area studies expertise, and who also have extensive experience in the practical world of foreign relations. Fulda, a comparativist who studies China, already had one foot in both the academic and policy worlds when he worked as a development professional while completing his doctorate. Murphy, an international relations scholar whose research focuses on Southeast Asia, has monitored elections, briefed congressional staffers, and conducted research commissioned by government agencies, and she reg- ularly participates in policy dialogues. While our specific academic expertise has helped us gain entry into the practical world, the insights we offer here are generic ones that are applicable to all political scientists.

\section{COMMISSIONED RESEARCH AND POLICY ANALYSIS}

Scholars are often commissioned to conduct research for governments, foundations, or NGOs that want specific questions answered but lack the expertise or time to carry out the necessary project. In these situations, the research question that the scholar attempts to answer is generated not by a theoretically deduced hypothesis-as in academic research-but in response to the needs of the commissioning policymakers and advocates. Typically, the commission is to answer an empirical question that has practical relevance for the commissioners. A scholar engaging in such work will sometimes also be called on to make recommendations based upon his or her findings. Scholars are usually compensated for their research and expenses, and before beginning a project, they are generally presented with contracts that outline the scope of work, a timeline for deliverables, a schedule of compensation, and an expense budget, if applicable.

For example, consider Murphy's experience undertaking commissioned research with the National Bureau of Asian Research (NBR). An independent organization that conducts research on issues affecting U.S. relations with Asia, NBR was created in response to Senator Henry M. Jackson's concern that policymakers lacked thorough analysis of Asian issues. ${ }^{1}$ NBR develops research guidelines for projects, but contracted specialists conduct the research, which is then subjected to peer review before publication. In 2007, an NBR officer who Murphy had previously met at conferences solicited her to research professional organizations in Indonesia. Home of the world's largest community of Muslims, Indonesia was in the process of transitioning to democracy, and the rise of political Islam was one of this shift's defining features. NBR wanted to know whether conservative Muslim activists were obtaining leadership positions in Indonesia's legal, medical, journalism, and business organizations and subsequently using this authority to advocate policies that were inconsistent with religious pluralism, gender equality, open markets, and good relations with the West. This question arose from the Egyptian experience, in which members of the Muslim Brotherhood had pursued a similar strategy (Wickham 2002). However, Murphy found that Indonesia's professional organizations were not being hijacked by conservative Muslim groups but 
were instead in the midst of dramatic reform that aimed to make themselves more democratic. In the end, Murphy wrote a confidential 55-page report on the subject, as well as a 17-page article that NBR published in tandem with a sister project on Malaysia (Murphy 2008).

Certain NGOs can also commission research. For example, Freedom House is an independent watchdog organization based in New York City that supports democratic change, monitors freedom, and advocates for democracy and human rights. Freedom in the World, its flagship publication, annually assesses the status of political rights and civil liberties in countries across the globe and rates countries according to how democratic they are. In Freedom in the World 2005, Murphy wrote the chapters on Indonesia, Thailand, and East Timor and participated in that year's country-rating meetings. Regime change is an issue of intense scholarly inquiry for political scientists (e.g., Huntington 1991; Snyder 200o; Stepan 2009), particularly for someone studying Southeast Asia, a region that encompasses both countries transitioning toward democracy, such as Indonesia, and countries experiencing a democratic reversal, such as Thailand. Murphy's commissioned work with Freedom House was beneficial for both parties. The NGO was able to tap into her independent skills and knowledge, and Murphy gained tremendous insight into how one of the indexes most commonly used by political scientists to measure democracy was developed.

Political scientists are sometimes asked to evaluate whether policies are achieving their goals and how they could do so more effectively. For example, Fulda was requested to review German development initiatives in China and assess how they could better promote good governance, enhance political participation, and strengthen Chinese civil society. His research found that when German development agencies partnered with organizations controlled by the Chinese government or the Chinese Communist Party, German efforts to advance these objectives were blocked. In contrast, when Germany worked with Chinese grassroots NGOs, political participation and civil society were strengthened. Fulda therefore recommended that Germany funnel a larger portion of its development assistance through NGOs.

These cases are only three examples of how commissioned research and policy analysis can provide opportunities for scholars to build upon existing expertise and explore new and often cutting-edge issues. One key difference between traditional scholarly research and policy research that these examples highlight is the importance of time constraints. Scholars face deadlines for conference papers and book contracts, but they also often have the luxury of taking the time to complete an article to their satisfaction before submitting it to a journal. Timelines for commissioned research, however, can be extremely tight and may coincide with university teaching and service obligations. For example, after accepting the NBR commission in September, Murphy was obligated to adhere to the following schedule of research activities and deadlines: attendance at an October planning workshop in Washington, DC; submission of a fully developed research plan in November; the commencement of data collection in November; a twoweek research trip to Indonesia in January; submission of a 55-page draft report in February; revision of the report in April; and presentation of the research findings at a Washington, DC, conference in May. The ability to work under tight deadlines to produce a quality project is a crucial skill required for scholars working on commissioned research.

\section{TRACK II DIPLOMACY AND POLICY DIALOGUES}

Moving along the spectrum toward more practical work, some scholars also participate in Track II conferences and other types of policy dialogues. Montville defines Track II diplomacy as "unofficial, informal interactions between members of adversary groups or nations which aim to develop strategies, influence public opinion, and organize human and material resources in ways that might help to resolve their conflict" (Montville 1995, 9). Track I dialogues, or government-togovernment meetings, are attended by officials who can typically only speak on the record and therefore must keep their remarks within the parameters of officially sanctioned policy. This constraint often restricts the scope of discussions, limiting the development of new ideas to help resolve conflicts. Track II conferences are designed to overcome these limitations by fostering the free exchange of ideas in off-therecord meetings involving policymakers in the role of private citizens and representatives from think tanks, academia, and other groups. Through this approach, Track II conferences can help channel scholarly research to policymakers. The Asia Society's annual Williamsburg conference, which brings together Asian and American leaders from government, business, and academia to discuss challenges facing the AsiaPacific community and develop collaborative proposals to address them, is a leading Track II conference and a prime example of Track II diplomacy. ${ }^{2}$

In contrast to Track II diplomacy, which involves participants from more than one country, policy dialogues and commissions that convene to discuss particular issues often only involve participants from one country, who may or may not be current government officials. Organizations such as the Council on Foreign Relations, the Brookings Institution, and the Foreign Policy Research Institute, for example, regularly convene workshops on topics as diverse as nuclear weapons, climate change, and maritime security and invite scholars with the appropriate expertise to participate. Think tanks in Washington, DC, often hold such conferences and produce policy papers for each incoming presidential administration. In fall 2008, for example, the Center for Strategic and International Studies (CSIS) organized a series of workshops about U.S. relations with Southeast Asian countries. CSIS commissioned reports on key bilateral relationships that the workshops then critiqued before proceeding to develop and debate policy recommendations. CSIS widely distributed the resulting 8o-page report, U.S. Alliances and Emerging Partnerships in Southeast Asia, to members of Congress, policymakers, journalists, think tanks, public intellectuals, and other individuals with influence in the policy process (Center for Strategic International Studies Southeast Asia Initiative 2009).

In contrast to academic conferences in which scholars present and discuss papers among themselves, these more policy-oriented conferences are structured to foster dialogue 
and spirited debate among a range of people in the foreign policy community. Background papers may be prepared in advance, but more important, organizers circulate a series of questions for participants to address. Such conferences are often chaired by a senior figure with a record of government service who ensures that the discussion remains on point. The criteria for a successful policy conference are somewhat different than those for an academic conference. In academia, the became part of the government's 2009 coalition agreement. In this case, policy advocacy was necessary to translate ideas into action.

\section{PATHWAYS TO SERVICE}

Opportunities for academics to engage in policy work typically arise when these individuals possess expertise that a member of the policy community requires but lacks in-house.

\section{In academia, the knowledge produced by good research is valued in its own right. In}

contrast, policymakers may only want to know how a scholar's research findings can impact national interests. This outlook can be particularly disconcerting for a political scientist with an area studies focus who cares deeply about the country and people that he or she studies. In fact, political scientists with deep knowledge of a particular region can be ineffective at such policy conferences if they cannot continually view events through the prism of U.S. national interests, which some scholars are loath to do.

knowledge produced by good research is valued in its own right. In contrast, policymakers may only want to know how a scholar's research findings can impact national intereststhat is, they are often only concerned with what happens "over there" if it affects them "over here." This outlook can be particularly disconcerting for a political scientist with an area studies focus who cares deeply about the country and people that he or she studies. In fact, political scientists with deep knowledge of a particular region can be ineffective at such policy conferences if they cannot continually view events through the prism of U.S. national interests, which some scholars are loath to do.

\section{POLICY ADVOCACY}

In perhaps one of the most practical of activities, scholars can also engage directly in the foreign policy process by lobbying governments on behalf of specific policies. In such cases, scholars resemble what Roberts and King call "public entrepreneurs," or individuals who advocate new ideas, develop proposals, define and reframe problems, specify policy alternatives, broker ideas among many policy actors, mobilize public opinion, and help set the decision making agenda (Roberts and King 1991, 148). In short, this type of engagement provides situations in which a scholar can use his or her knowledge to participate fully in the policymaking process.

Fulda became a policy advocate when his recommendation that German development assistance be channeled through Chinese NGOs became bogged down in bureaucratic politics between Germany's Ministry of Foreign Affairs, Ministry of Economic Cooperation and Development, and its various development agencies. Realizing that the implementation of his recommendation would require political pressure, Fulda lobbied members of parliament who had oversight of development programs. Finding common ground with the German Liberal Party, he helped draft a parliamentary motion calling for greater German assistance for Chinese grassroots NGOs, which ultimately
The policy community tends to seek out scholars with certain technical expertise when international events, particularly crises, create an increased demand for specialized knowledge. For example, scholars whose research focused on terrorism were in high demand following the September 11 attacks on the United States. Murphy's first opportunity to engage the policy community occurred in 1998, when Indonesia's economy contracted $13.8 \%$, leading to the overthrow of General Suharto after three decades in power and triggering social violence in parts of the country. As fears in Washington, DC, grew that Indonesia would become another Yugoslavia-an extremely diverse society violently breaking apart at the end of authoritarian rule-the policy community sought out academics who could provide information on the backgrounds and interests of new political actors; analysis regarding potential political scenarios; and advice on what, if anything, the U.S. government could do to influence unfolding events in a positive way.

To obtain an invitation to participate in these sorts of service activities, scholars must make themselves and their work known to members of the policy community. Typically, a scholar's writing or citations bring him or her to the attention of policymakers. Since a disjuncture exists between what scholars and policymakers read, this notice often requires scholars to publish in new venues. The diplomatic community tends to read Foreign Affairs, the Washington Quarterly, and Foreign Policy, rather than International Security, International Organization, and World Politics. Often, it may be possible to incorporate the development of essays written explicitly for these more policy-oriented outlets into your research program. For example, if you are conducting a study of the International Monetary Fund, you may be able to spin off an article for Foreign Policy on the fund's role in the current economic crisis. These journals are not interested in academic theory or jargon. Rather, they are looking for sharp analysis of contemporary issues written in an engaging 
manner for an audience of informed generalists. It is helpful to read these journals to get a feel for their style and the sort of information and discussion they publish. ${ }^{3}$ If you think you have something to contribute to these fora, submit a short "pitch" describing the proposed article's key themes and explaining its importance to the journal's readers. If the editors like your idea, they will provide feedback on how to develop the article for the journal's audience. If they pass, your time investment has been minimal.

Political scientists can also raise their profile in the policy community by speaking to the mass media and writing opinion pieces. Universities typically welcome the publicity that results when faculty engage the broader community and can often assist in these efforts. University communications offices normally have close ties with local newspapers and can put reporters seeking expertise in contact with scholars who can provide it. Universities may also provide media training to faculty in preparation for radio and television interviews.

When a significant international event in your area of expertise occurs, be on the lookout for opportunities to get involved. If you think that the media is portraying a situation incorrectly, write a commentary analyzing the flaws in the reporting, and-more important-highlighting the policy implications of your analysis. What course of action would a policymaker who subscribes to your interpretation of events advocate? How does your recommendation differ from the current policy, and why does this difference matter? Circulate your analysis as widely and as quickly as possible. Timeliness is critical. International events often develop rapidly, and a brilliant analysis of yesterday's problem is utterly worthless to policymakers today. Websites and blogs maintained by many policy journals to encourage debate on current issues are good outlets for such writings.

Political scientists sometimes gain entry to the policy community through personal ties, such as a recommendation from a senior colleague. If you are not lucky enough to have a mentor who can help open doors for you, there are a number of other ways to develop your own network. For example, the Bridging the Gap project holds an annual week-long professional development program for post-doctoral students and assistant professors in the field of international relations who seek to acquire the tools and develop the networks necessary to pursue and disseminate policy-relevant academic research. ${ }^{4}$ The Women in International Security project at Georgetown holds an annual six-day summer symposium in Washington, DC, that brings graduate students into contact with experienced professionals who can mentor them. ${ }^{5}$ Many policy professionals attend the annual conferences of the APSA and the International Studies Association, which are prime opportunities for networking.

\section{THE BENEFITS OF POLICY WORK FOR TEACHING AND RESEARCH}

Perhaps the greatest benefit of this type of public service to academic scholarship is that participation in projects sponsored by governments, think tanks, and NGOs provide invaluable opportunities to interview policymakers and gather data that are not normally publicly accessible. For example, Murphy's par- ticipation in a 2009 Track II conference on U.S.-Indonesian relations organized by the Indonesian embassy in Washington, DC, provided an opportunity to hear officials from both sides candidly assess the relationship's strengths and weaknesses. However, policy conferences typically operate under Chatham House rules, meaning that everything said during them is off the record. Scholars can use the insights gained in these venues to help understand and interpret policy, but they must be careful to not betray the confidentiality of the information for ethical and practical reasons. Someone who is perceived as violating these norms will likely lose any future opportunities for this type of service. The confidentiality of some foreign affairs policy work can put it at odds with the scholarly commitment to replicable scientific results and transparency. Some workarounds are possible, however: scholars can occasionally find public references for arguments made in private meetings, enabling them to enrich their scholarship while maintaining their commitment to confidentiality.

This sort of policy work also helps bring real-world concerns into the classroom, thus enhancing the teaching and learning experiences. Public service provides a teacher with insights into how officials view problems and a real appreciation for the constraints that government officials must face as they grapple with unfolding situations. Such experience helps in fleshing out theoretical models of decision-making that stress rationality and value-maximizing behavior. As political scientist and former assistant secretary of defense Joseph Nye has lamented, "Too often scholars teach theory and methods that are relevant to other academics but not to the majority of the students sitting in the classroom" (Nye 2009). Public service can help overcome this pitfall by engaging students with exciting specific information and ideas, as well as giving the instructor credibility, which encourages greater student attention and respect.

Political scientists who engage in such activities can also serve as better mentors to students who aspire to careers in foreign affairs, because of their increased appreciation for how government works. The network of contacts developed through policy activities can also be very beneficial in helping students find internships and jobs as they transition into the professional world.

Finally, and perhaps least significant, policy work can be financially rewarding. Remuneration for commissioned research may be determined on a project basis, an hourly basis, or some combination thereof. For example, Murphy's commissioned work for NBR in 2007-08 provided a stipend, a research assistant, and expenses for a two-week research trip to Indonesia. Organizations sponsoring policy dialogues and Track II conferences may pay scholars honoraria in addition to covering their travel expenses. Particularly when these events are held overseas, policy work can be an important way to supplement limited university travel budgets. Any time a scholar accepts compensation from an outside source, however, conflict of interest questions may arise. A scholar offered compensation by an organization should familiarize him or herself with its funding sources and political positions and consider any potential risks to his or her academic reputation before accepting it. 


\section{RISKS}

While potentially exciting and fulfilling, practical policy work can pose a series of risks for a scholarly career. Maintaining academic integrity and scholarly independence may be tough when conducting service in a field that is often intensely partisan. This risk increases as you move along the continuum from academia toward the policy world. Conducting commissioned research for nonpartisan organizations can be the least threatening activity, especially if the research is intended to provide background information and is not directly involved in the policy process. Once you choose to move beyond the assessment of policy implications to policy proposals and advocacy, you risk alienating colleagues in your department, university, and profession who do not share your views. For issues such as poverty alleviation, the risk may be small. For more controversial issues on which passions run high, such as the Iraq war or the Israeli-Palestinian conflict, publicly taking sides may lead others to question the integrity of your scholarship, which can have potentially deleterious consequences both on and off campus. In particular, opponents may examine your scholarship closely to uncover flaws or try to discredit a scholar's work for spurious but politically significant reasons.

Policy work may also negatively impact one's academic career prospects. Publications in policy journals-one avenue into the policy world-are typically not given as much weight in tenure and promotion decisions as in more academic, peerreviewed journals. Similarly, speaking at policy workshops and participating in Track II conferences are often considered public service and not scholarship, regardless of the amount of research that effective participation in these endeavors requires. Since time constraints limit the number of conferences anyone can attend, policy conferences can crowd out academic ones. If you are considering participating in such activities, solicit advice about how this engagement will be viewed in tenure and promotion decisions by department and university colleagues. Deans and other administrators who have an interest in raising the public profile of the university may actually encourage such efforts, whereas your faculty colleagues may not share this enthusiasm. In particular, untenured faculty should make sure they are fully aware of how those reviewing their tenure applications are likely to view their practical policy work and should plan their time accordingly.

\section{CONCLUSION}

Practical foreign policy work can be demanding and stressful, and because its events-driven timing typically does not coincide with the academic calendar, it can wreak havoc on well- planned teaching and research schedules. However, this work can also be immensely personally and professionally gratifying, particularly when your ideas can be translated into policy. We believe that our policy work has enriched our research and teaching and rounded out our careers in important ways. If scholars truly believe in the power of ideas to effect positive change, then it is incumbent upon them to attempt to put those ideas into practice. We encourage scholars to explore where they may best make a contribution along the wide spectrum linking the academic and practical worlds of foreign policy.

\section{NOTES}

1. NBR receives funding from foundations, corporations, and the U.S. government. More information on NBR is available at http://www.nbr.org.

2. For more information on the Williamsburg Conference, see http:// asiasociety.org/policy-politics/williamsburg-conference/aboutwilliamsburg-conference.

3. Information on these journals, including submission procedures, can be found at http://www.foreignpolicy.com/articles/writers_guidelines, http:// www.foreignaffairs.com/about-us/submissions, and http://www.twq.com/ info/about.cfm

4. For more information on the Bridging the Gap project, see http:// www.gwu.edu/ btg/.

5. For more information on the Women in International Security project, see http://wiis.georgetown.edu.

\section{REFERENCES}

Center for Strategic International Studies Southeast Asia Initiative. 2009. U.S Alliances and Emerging Partnerships in Southeast Asia. Washington, DC: Center for Strategic International Studies.

George, Alexander L. 1993. Bridging the Gap: Theory and Practice in Foreign Policy. Washington, DC: United States Institute of Peace.

Huntington, Samuel P. 1991. The Third Wave: Democratization in the Late Twentieth Century. Norman: University of Oklahoma Press.

Montville, Joseph V. 1995. "The Arrow and the Olive Branch: A Case for Track Two Diplomacy.” In Conflict Resolution: Track Two Diplomacy, ed. John W. MacDonald and Diane B. Bendahmane. Washington, DC: Institute for Multi-Track Diplomacy.

Murphy, Ann Marie. 2008. "The Rose of Professional Organizations in Indonesia's Socio-Political Transformation.” NBR Analysis 18 (3): 17-34.

Nye, Joseph S., Jr. 2009. "Scholars on the Sidelines." Washington Post, April 13.

Roberts, N. C., and P. J. King. 1991. "Policy Entrepreneurs: Their Activity Structure and Function in the Policy Process." Journal of Public Administration Research and Theory 1: 148-50.

Snyder, Jack L. 20oo. From Voting to Violence: Democratization and Nationalist Conflict. New York: Norton.

Stepan, Alfred. 2009. Democracies in Danger. Baltimore: Johns Hopkins University Press.

Wickham, Carrie Rosefsky. 2002. Mobilizing Islam: Religion, Activism and Political Change in Egypt. New York: Columbia University Press. 


\section{What's New in Political Science?}

\section{Cambridge Studies in Comparative Politics}

Quiet Politics and Business Power

Corporate Control in Europe and Japan Pepper D. Culpepper \$90.00: Hb: 978-0-521-11859-0: 248 pp. \$29.99: $\mathrm{Pb}: 978-0-521-13413-2$

Framing the Race in South Africa The Political Origins of Racial Census Elections Karen E. Ferree \$90.00: Hb: 978-0-521-76509-1: 312 pp.

Labor Rights and Multinational Production Layna Mosley \$85.00: Hb: 978-0-521-87281-2: 312 pp. \$28.99: Pb: 978-0-521-69441-4

\section{Civil Religion}

A Dialogue in the History of Political Philosophy Ronald S. Beiner \$95.00: Hb: 978-0-521-50636-6: $448 \mathrm{pp}$. \$34.99: Pb: 978-0-521-73843-9

\section{Politics in Dark Times} Encounters with Hannah Arendt Edited by Seyla Benhabib \$90.00: Hb: 978-0-521-76370-7: 408 pp. \$28.99: Pb: 978-0-521-12722-6

\section{Elections and Distributive} Politics in Mubarak's Egypt Lisa Blaydes

\$90.00: Hb: 978-1-107-00055-1: 288 pp.

Policy Diffusion Dynamics in America

Graeme T. Boushey

\$85.00: Hb: 978-0-521-76281-6: 240 pp.

\section{Dismantling Democracy}

in Venezuela

The Chávez Authoritarian Experiment Allan Brewer-Carías

\$115.00: Hb: 978-0-521-19587-4: 432 pp. \$39.99: Pb: 978-0-521-14557-2
The Practice of Global Citizenship

Luis Cabrera

\$90.00: Hb: 978-0-521-19936-0: 328 pp. \$31.99: Pb: 978-0-521-12810-0

Imperial Sceptics

British Critics of Empire, 1850-1920

Gregory Claeys

Ideas in Context

\$95.00: Hb: 978-0-521-19954-4: 456 pp.

The Limits of

Judicial Independence

Tom S. Clark

Political Economy of

Institutions and Decisions

\$90.00: Hb: 978-0-521-19488-4: 352 pp. \$29.99: Pb: 978-0-521-13505-4

Cosmopolitan Power in International Relations A Synthesis of Realism, Neoliberalism, and Constructivism Giulio M. Gallarotti

\$85.00: Hb: 978-0-521-19007-7: 334 pp. \$29.99: Pb: 978-0-521-13812-3

Voluntary Regulation of NGOs and Nonprofits An Accountability Club Framework Edited by Mary Kay Gugerty and Aseem Prakash

\$90.00: Hb: 978-0-521-76314-1: 322 pp.

The Transformation of the

Workers' Party in Brazil, 1989-2009

\section{Wendy Hunter}

\$85.00: Hb: 978-0-521-51455-2: $252 \mathrm{pp}$. \$29.99: Pb: 978-0-521-73300-7

\section{Morgenthau,}

Law and Realism

Oliver Jütersonke

\$85.00: Hb: 978-0-521-76928-0: 212 pp.

Religion and the

Political Imagination

Edited by Ira Katznelson

and Gareth Stedman Jones

\$95.00: Hb: 978-0-521-76654-8: 394 pp. \$29.99: Pb: 978-0-521-14734-7
Why Nations Fight

Past and Future

Motives for War

Richard Ned Lebow

\$99.00: Hb: 978-0-521-19283-5: 318 pp. \$29.99: Pb: 978-0-521-17045-1

\section{Competitive}

\section{Authoritarianism}

Hybrid Regimes

After the Cold War

Steven Levitsky

and Lucan A. Way

Problems of International Politics

\$95.00: Hb: 978-0-521-88252-1: $536 \mathrm{pp}$. \$29.99: Pb: 978-0-521-70915-6

\section{Obama's Bank}

Financing a Durable New Deal Michael Likosky

\$75.00: Hb: 978-0-521-19754-0: 392 pp. \$24.99: Pb: 978-0-521-14711-8

Oil Wealth and the

Poverty of Politics

Algeria Compared

Miriam R. Lowi

Cambridge Middle East Studies

\$93.00: Hb: 978-0-521-11318-2: 250 pp.

History and Neorealism

Edited by Ernest R. May,

Richard Rosecrance,

and Zara Steiner

\$99.00: Hb: 978-0-521-76134-5: $406 \mathrm{pp}$

\$33.99: Pb: 978-0-521-13224-4

\section{Constituency}

Representation

in Congress

The View from Capitol Hill

Kristina C. Miler

\$85.00: Hb: 978-0-521-76540-4: 224 pp.

\section{Experimental}

Political Science and the

Study of Causality

From Nature to the Lab

Rebecca B. Morton and Kenneth C. Williams

\$110.00: Hb: 978-0-521-19966-7: 606 pp. \$39.99: Pb: 978-0-521-13648-8
Owning Development Creating Policy Norms in the IMF and the World Bank Edited by Susan Park and Antje Vetterlein \$90.00: Hb: 978-0-521-19895-0: $306 \mathrm{pp}$

U.S. Leadership, History, and Bilateral Relations in Northeast Asia

Edited by Gilbert Rozman \$85.00: Hb: 978-0-521-19056-5: 248 pp.

War, the American State, and Politics since 1898

Robert P. Saldin \$90.00: Hb: 978-0-521-11915-3: $272 \mathrm{pp}$.

Genocide and the Europeans Karen E. Smith

\$90.00: Hb: 978-0-521-11635-0: 288 pp. \$31.99: Pb: 978-0-521-13329-6

Political Philosophy

An Introduction

Richard G. Stevens

\$90.00: Hb: 978-1-107-00043-8: $352 \mathrm{pp}$. $\$ 27.99: \mathrm{Pb}: 978-0-521-16901-1$

Cultures of Power in Post-Communist Russia An Analysis of Elite Political Discourse Michael Urban \$85.00: Hb: 978-0-521-19516-4: 228 pp.

The CDU and the Politics of Gender in Germany Bringing Women to the Party Sarah Elise Wiliarty \$85.00: Hb: 978-0-521-76582-4: $284 \mathrm{pp}$

\section{Building}

Transnational Networks

Civil Society and the Politics of Trade in the Americas Marisa von Bülow

Cambridge Studies in Contentious Politics

\$80.00: Hb: 978-0-521-19156-2: 280 pp Prices subject to change. 